JPdK Volume 3 Nomor 2 Tahun 2021 Halaman 91-95

JURNAL PENDIDIKAN dan KONSELING

Research \& Learning in Primary Education

\title{
Analisis Kesulitan Belajar Matematika pada Siswa SMP di Masa Pandemi Covid-19
}

\author{
Nanang Setiawan', Putri Nur Azizah ${ }^{2}$, Vara Erni Yuwanita ${ }^{3}$, Viki Masruroh ${ }^{4}$, Pebriani Rahmawati $^{5}$, \\ Seftiana Mardikasari $W^{6}$, Darmadi ${ }^{7}$ \\ Program Studi Pendidikan Matematika, \\ Fakultas Keguruan dan Ilmu Pendidikan, \\ Universitas PGRI Madiun
}

E-mail : nanang0508200@gmail.com, siputrinurazizah21@gmail.com, varaerniyuwanita38@ gmail.com, vikimasruroh123@gmail.com, rahmawati.febriani@gmail.com, seftiana878@ gmail.com, darmadi7868482@yahoo.com

\begin{abstract}
Abstrak
Pandemi Covid-19 telah berdampak pada berbagai bidang, salah satunya dalam bidang pendidikan. Selama pandemi ini menyebabkan pembelajaran tatap muka di kelas tidak berjalan dengan semestinya, berubah menjadi sistem pembelajaran daring. Penelitian ini bertujuan untuk mendeskripsikan kesulitan belajar siswa khususnya mata pelajaran matematika di jenjang SMP pada masa pandemi. Jenis penelitian yang digunakan adalah kualitatif deskriptif. Instrumen yang digunakan adalah berupa angket online. Kesimpulan dari penelitian ini adalah kebanyakan siswa menggunakan WhatsApp sebagai media pembelajaran daring. Kendala yang dialami siswa saat pembelajaran daring yang paling umum dikarenakan kendalajaringan internet yang kurang di sebagian tempat siswa dan kuota internet. Selain itu, matematika juga menjadi kesulitan dan tantangan tersendiri bagi siswa saat pembelajaran daring dikarenakan beberapa faktor, yaitu: (1) terlau banyak soal matematika yang diberikan, (2) terbatasnya ruang interaksi dengan guru, (3) objek yang dipelajari abstrak, (4) terlalu banyak rumus.
\end{abstract}

Kata Kunci: Pandemi, Matematika, Pembelajaran Daring

\begin{abstract}
The Covid-19 pandemic has had an impact on various fields, one of which is in the field of education. During this pandemic, face-to-face learning in class did not run properly, turning into an online learning system. This study aims to describe students' learning difficulties, especially mathematics at the junior high school level during the pandemic. The type of research used is descriptive qualitative. The instrument used is an online questionnaire. The conclusion of this study is that most students use WhatsApp as an online learning medium. The most common obstacles experienced by students during online learning are due to the lack of internet network constraints in some student places and internet quotas. In addition, mathematics also becomes its own difficulties and challenges for students when learning online due to several factors, namely: (1) too many math problems are given, (2) limited space for interaction with teachers, (3) abstract objects studied, (4) too many formulas.
\end{abstract}

Keywords: Pandemic, Mathematics, Online Learning 


\section{PENDAHULUAN}

Dunia tengah digemparkan dengan adanya virus yang bernama Corona Virus Disease sejak 2019 yang lalu, atau bisa disebut Covid-19. Virus ini tengah menyebabkan puluhan juta jiwa terinfeksi dan menyebar ke sebagian negara. Penyebaran virus ini telah mempengaruhi berbagai bidang diseluruh dunia, khususnya bidang pendidikan di Indonesia. (Herliandry, Nurhasanah, Suban, \& Kuswanto, 2020). Menurut UU No. 20 tahun 2003, Pendidikan adalah usaha sadar dan terencana untuk mewujudkan suasana belajar dan proses pembelajaran agar peserta didik secara aktif mengembangkan potensi dirinya untuk memiliki kekuatan spiritual, pengendalian diri, kepribadian, kecerdasan, akhlak mulia, serta ketrampilan yang diperlukan dirinya, masyarakat, bangsa, dan negara. Dikarenakan pada musim pandemi tersebut, banyak negara di dunia memutuskan untuk memberhentikan sekolah tatap muka dari tingkat taman kanan-kanak hingga setingkat perguruan tinggi, termasuk di Indonesia (Syah, 2020)

Berdasarkan permasalahan tersebut, pemerintah melalui Peraturan Menteri Kesehatan Nomor 9 Tahun 2020 berusaha untuk meminimalisir penyebaran virus dengan cara mengeluarkan larangan untuk berkerumun dan memberlakukan PSBB hampir di setiap daerah di Indonesia. Menteri bidang Pendidikan dan kebudayaan Tahun 2020 Nomor 36962/MPK.A/HK/2020, juga menginstruksikan agar proses belajar mengajar dilakukan secara daring untuk mengupayakan pencegahan penyebaran COVID-19.

Pembelajaran daring adalah pembelajaran yang dilakukan secara jarak jauh menggunakan media internet dan perangkat bantu lainnya seperti telepon seluler, laptop dan komputer (Putria, Maula, \& Uswatun, 2020). Akan tetapi dalam faktanya, pembelajaran daring tidak bisa dilakukan seacar maksimal seperti pembelajaran di kelas, terutama pada pelajaran matematika. Matematika merupakan salah satu mata pelajaran yang diajarkan kepada siswa mulai dari tingkat pendidikan dasar sampai pada tingkat pendidikan tinggi. Hal itu menunjukkan pentingnya penguasaan siswa pada mata pelajaran matematika. Matematika tidak semata-mata dipandang sebagai mata pelajaran saja, namun juga penerapannya pada kehidupan sehari-hari. Penguasaan matematika yang mendukung berpikir rasional sangat berpengaruh pada kecerdasan analisa seseorang dalam menyelesaikan permasalahan seharihari. Prestasi belajar rendah yang ditemukan pada beberapa siswa merupakan bukti adanya kesulitan siswa dalam belajar matematika. Peran tenaga pendidik ketika proses pembelajaran daring berlangsung untuk membantu memberikan pemahaman kepada siswa sangat dibutuhkan dalam hal ini untuk menemukan solusi pemecahan masalah.

Kesulitan yang ditemukan siswa dalam belajar dapat disebabkan oleh dua faktor, yaitu internal dan eksternal. Faktor internal merupakan berasal dari diri siswa masing-masing, misalnya bakat, minat, dan intelegensi dan sebagainya. Sedangkan faktor eksternal merupakan faktor yang berasal dari luar diri siswa, misalnya lingkungan teman, keluarga dan sekolah. Menurut Rusfendi (2009 : 76) belajar matematika yang baik : " Agar anak didik memahami dan mengerti konsep matematika, seyogyanya diajarkan dengan urutan konsep murni selanjutnya dengan konsep terapan di samping itu harus disesuaikan dengan tingkat proses anak disik atau peserta didik belajar." Dari hasil ini peneliti ingin sekali meneliti lebih jauh tentang keaktifan siswa dan penyebab kesulitan siswa SMP dalam pembelajaran matematika secara daring saat masa pandemi.

\section{METODOLOGI PENELITIAN}

Metode penelitian yang digunakan adalah kualitatif deskriptif, untuk memberikan gambaran pembelajaran daring pada siswa SMP . Penelitian kualitatif merupakan metode penelitian naturalistic dikarenakan penelitiannya dilaksanakan pada kondisi yang apa adanya (natural setting) (Sugiyono, 2015:14). Teknik untuk mengumpulkan data dengan metode survey, yaitu dengan melakukan penyebaran angket secara online. Angket tersebut disebarkan secara acak kepada responden melalui Google Form yang dikirimkan melalui pesan WhatsApp. Subjek penelitian ialah siswa SMP. Total responden yang berhasil mengisi angket sampai tenggat waktu yang telah dijadwalkan adalah sebanyak 23 responden. Adapun indikator dari angket yang disebarkan terdiri dari: Pelaksanaan pembelajaran daring dan kesulitan pembelajaran daring matematika. Hasil dari isian angket kemudian dipersentasekan dan di deskripsikan sesuai dengan indikator-indikator yang terdapat di dalam angket.

Tabel 1. Kisi-kisi Angket

\begin{tabular}{|l|l|l|}
\hline No & \multicolumn{1}{|c|}{ Aspek } & Nomor \\
\hline 1. & $\begin{array}{l}\text { Pelaksanaan } \\
\text { Pembelajaran } \\
\text { Daring }\end{array}$ & $1,2,3$ \\
\hline 2. & $\begin{array}{l}\text { Kesulitan } \\
\text { Pembelajaran } \\
\text { Daring } \\
\text { Matematika }\end{array}$ & $4,5,6$ \\
\hline
\end{tabular}




\section{HASIL PENELITIAN DAN PEMBAHASAN}

Instrumen yang menjadi rujukan untuk analisis kesulitan belajar matematika pada siswa SMP pada masa pandemi adalah dengan cara menyebarkan angket online melalui whatsapp. Berdasarkan hasil angket yang disebar, ditemukan beberapa hasil terkait pembelajaran daring. Pada indicator pertama, yaitu pelaksanaan pembelajaran daring digambarkan dengan tiga item pernyataan yang diterapkan pada no 1, 2, 3. Berdasarkan hasil data yang diperoleh pada angket no. 1 tentang "apakah siswa mengikuti pembelajaran daring (online) di masa pandemi ini?". Berdasarkan hasil angket no. 1 dapat dilihat datanya pada gambar 1 yang menunjukkan bahwa hasil yang diperoleh masih banyak siswa yang mengikuti pembelajaran secara daring. Perhatikan persentase data yang diperoleh pada angket no. 1 berikut.

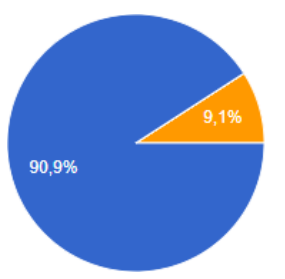

Ya

Tidak

Gambar 1. Persentase Siswa Mengikuti Pembelajaran Daring

Pada gambar 1, dapat disimpulkan bahwa minat untuk mengikuti pembelajaran daring masih tinggi dengan persentase $90,9 \%$. Persentase tersebut tinggi disebabkakan karena pembelajaran daring merupakan salah satu cara yang diterapkan pemerintah untuk mengatasi masa pandemic sehingga pembelajaran di sekolah tetap dapat dilaksanakan. sehingga para siswa tidak ketinggalan pelajaran terlalu jauh. Meskipun pembelajaran daring ini tidak jarang menimbulkan siswa kesulitan saat memahami materi.

Pada kegiatan pembelajaran daring, pastinya tenaga pendidik maupun siswa menggunakan perangkat lunak atau aplikasi sebagai sarana belajar mengajar. Pada angket no. 2 peneliti bertanya tentang "aplikasi apa yang sering digunakan ketika pembelajaran daring?". Berdasarkan hasil angket no.

2 dapat dilihat data pada gambar 2 yang menunjukkan bahwa hasil yang diperoleh kebanyakan siswa dan guru menggunakan aplikasi whatsapp.

Berikut dapat dilihat persentase data yang diperoleh angket no. 2
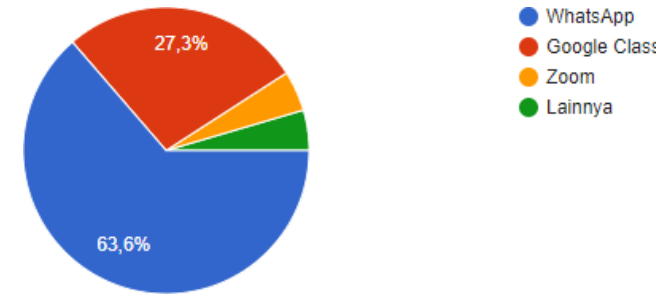

Google Classrom

Zoom

Lainnya

Gambar 2. Persentase Aplikasi Paling Diminati Ketika Pembelajaran Daring

Pada gambar 2 dapat terlihat jika Whatsapp menjadi aplikasi yang paling diminati ketika pembelajaran daring dengan persentase 63,6\%. Pada gambar tersebut dapat disimpulkan bahwa Whatsapp menjadi aplikasi paling banyak digunakan ketika pembelajaran daring dikarenakan aplikasi tersebut familiar dikalangan banyak orang karena rata-rata guru dan siswa memiliki aplikasi Whatsapp di Hp masingmasing. Dewi, Gunawan et al., Purwanto et al., (Setyorini, 2020), mengatakan bahwa pembelajaran daring saat ini paling banyak dilakukan menggunakan aplikasi Whatsapp dikarenakan rata-rata guru dan siswa memiliki aplikasi Whatsapp di Handphone nya masingmasing. Selain itu, diantara kelebihan Whatsapp adalah ketika jaringan sedang tidak stabil tetap bisa digunakan ketika pembelajaran daring. Penggunaan media aplikasi Whatsapp lebih irit paket data serta materi dapat di upload dengan mudah. Aplikasi kedua paling diminati setelah aplikasi Whatsapp adalah Google Classroom. Penggunaan aplikasi Google Classrom banyak digunakan karena aplikasi tersebut sudah familiar di kalangan guru dan siswa. Selain itu, aplikasi Google Classroom tidak menghabiskan banyak kuota serta materi yang di upload pada Google Classroom dapat di upload dengan mudah. Pada aplikasi Google Classroom siswa dapat melihat sendiri hasil nilai ujian maupun tugas.

Pada angket no. 3 peneliti bertanya tentang "apa kendala yang sering terjadi dalam pelaksanaan pembelajaran daring?". Berdasarkan hasil angket no. 3 dapat dilihat data pada gambar 3 yang menunjukkan bahwa kendala yang sering terjadi dalam pelaksanaan pembelajaran daring adalah sinyal.

Berikut dapat dilihat persentase data yang diperoleh pada angket no. 3
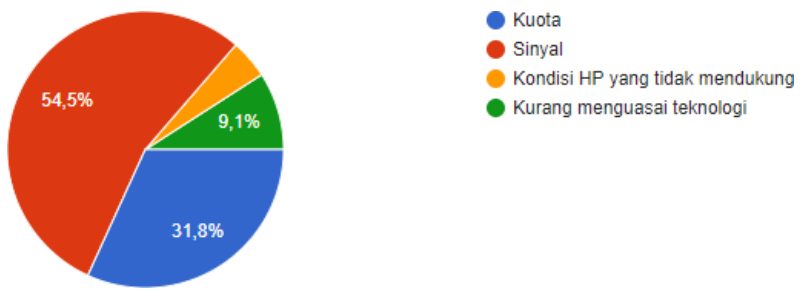

Gambar 3. Persentase Kendala Ketika Pembelajaran Daring 
Pada gambar no. 3 dapat dilihat jika kendala yang sering terjadi pada pembelajaran daring adalah masalah sinyal yaitu sebesar 54,5\%. Pada gambar tersebut dapat disimpulkan bahwa sinyal menjadi kendala utama pada pembelajaran daring hal ini dikarenakan lokasi tempat tinggal siswa yang berada jauh dari jangkauan jaringan internet. Jaringan internet menjadi salah satu unsur penting untuk mendukung pembelajaran daring. Tanpa adanya jaringan internet yang baik, pembelajaran yang dilaksanakan tidak bisa berjalan maksimal. Sehingga keadaan ini tidak jarang mempengaruhi prestasi siswa. Kendala selanjutnya yang dialami siswa yaitu kuota internet. Pada gambar 3 dapat dilihat jika persentase kuota internet sebesar 31,8\%. Para siswa mengeluhkan jika mereka sering kehabisan kuota ketika pembelajaran daring meskipun saat ini pemerintah memberikan bantuan kuota gratis. Penyebab kuota internet cepat habis dikarenakan tugas siswa yang banyak sehingga mereka juga membutuhkan kuota untuk browshing menemukan informasi saat mereka kurang paham terhadap penjelasan yang guru sampaikan. Sehingga penggunaan kuota semakin meningkat mengingat saat ini semua aktivitas dilaksanakan secara daring.

Pada indicator kedua, yaitu mengenai kesulitan pembelajaran daring matematika tergambar pernyataan no 4, 5, 6 pada angket yang disebarkan. Matematika adalah salah satu ilmu yang memiliki peran signifikan, karena matematika berguna untuk kehidupan sehari-hari manusia baik segi teknologi maupun ketika membangun daya piker manusia. Sehingga matematika diajarkan kepada siswa mulai jenjang TK, SD, SMP, SMA sampai Perguruan Tinggi. Akan tetapi, hal tersebut tidak sesuai kenyataan karena masih ada siswa yang kurang berminat belajar matematika, apalagi saat pembelajaran dilaksanakan secara daring hal tersebut dikarenakan siswa merasa kesulitan menerima pelajaran matematika saat daring. Pada angket no. 4 peneliti bertanya tentang "apakah kamu sangat antusias belajar matematika di dalam pembelajaran daring?". Berdasarkan angket no. 4 dapat dilihat pada gambar 4 masih banyak siswa yang antusias belajar matematika. Berikut persentase data pada angket no. 4
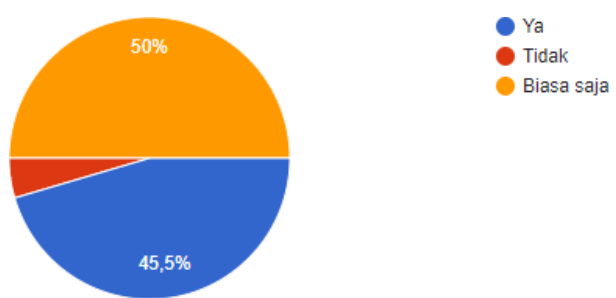

Gambar 4. Persentase Antusias Siswa Saat Mengikuti Pembelajaran Matematika Daring
Pada gambar no. 4 dapat dilihat jika antusias belajar matematika di pembelajaran daring masih cukup tinggi yaitu sebesar 45,5\%. Antusias belajar matematika yang cukup tinggi artinya siswa tetap minat untuk belajar matematika meskipun terkadang siswa mengeluh ketika belajar matematika karena kesulitan memahami materi. Siswa kesulitan memahami materi tersebut karena mereka tidak memahami konsep, mereka hanya menghafal rumus sehingga ketika disajikan pertanyaanpertanyaan yang sulit mereka tidak bisa mengerjakan. Sehingga disini peran guru dibutuhkan untuk menanamkan konsep matematika pada siswa, tidak hanya menghafal rumus sehingga mereka bisa menjawab pertanyaan sulit dengan mudah.

Pada angket no. 5 peneliti bertanya tentang "apakah kamu paham ketika pembelajaran matematika dilakukan secara daring?”. Berdasarkan angket no. 5 dapat dilihat pada gambar 5 perbandingan antara siswa yang paham dengan siswa yang cukup paham yaitu sama. Berikut persentase angket no. 5

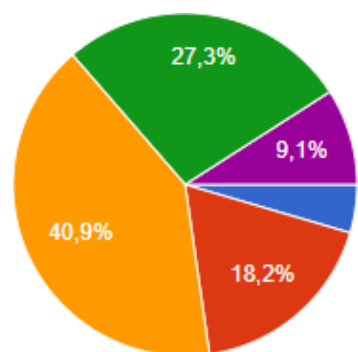

$$
\begin{aligned}
& \text { Sangat Paham } \\
& \text { Paham } \\
& \text { Cukup Paham } \\
& \text { Kurang Paham } \\
& \text { Tidak Paham }
\end{aligned}
$$

Gambar 5. Persentase Pemahaman Matematika Siswa Saat Mengikuti Pembelajaran Daring

No. 5 dapat dilihat persentase siswa yang sangat paham, paham dan cukup paham ketika pembelajaran matematika dilaksanakan secara daring yaitu sama sebesar 63,4\%. Sehingga dapat disimpulkan ketika pembelajaran daring mereka tetap menyimak materi, mereka tetap semangat menuntut ilmu agar citacita mereka dapat tercapai. Selain itu, teknologi semakin canggih, ketika mereka tidak paham mereka bisa browshing youtube, bertanya kepada teman, atau bertanya guru les, karena saat ini bimbel sudah banyak. Sehingga referensi yang mereka dapat semakin banyak tidak hanya mengandalkan guru.

Pada angket no. 6 peneliti bertanya "factor apa saja yang menyebabkan kamu mengalami kesulitan dalam memahami materi matematika dalam pembelajaran daring?”.

Berdasarkan gambar no. 6 faktor yang menyebabkan kesulitan dalam memahami materi matematika karena terlalu banyak rumus. Berikut persentase angket no. 6 


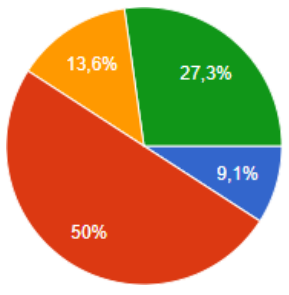

Terlalu banyak soal yang diberika Terbatasnya ruang interaksi denga

Objek yang dipelajari abstrak

- Sulit karena terlalubanyak rumus

Gambar 6. Persentase Penyebab Siswa Kesulitan Memahami Materi Daring Matematika

No. 6 dapat dilihat persentase factor yang menyebabkan siswa kesulitan dalam memahami materi matematika karena terbatasnya ruang interaksi dengan guru sebesar 50,0\%. Sehingga menyebabkan siswa kebingungan ketika memahami konsep dasar matematika. Sebenarnya terbatasnya ruang interaksi dengan guru tidak menjadi masalah saat siswa sudah paham konsep-konsep matematika, tetapi acuan mereka disini hanya menghafal rumus. Sehingga mereka kesulitan saat menjawab pertanyaan. Factor penyebab selanjutnya yaitu objek yang dipelajari abstrak. Chambers, 2008 (Novferma, 2016) Mengungkapkan matematika merupakan suatu bidang ilmu yang erat kaitannya dengan polapola abstrak yang memiliki ciri khas untuk memecahkan masalah. Adapun solusi yang bisa menjadi alternative guru untuk menghadapi permasalahan pembelajaran daring adalah dengan berupaya sebaik mungkin untuk menyajikan pembelajaran yang menarik, kreatif dan menyenangkan, terutama pada pembelajaran matematika. Anugrahana (2020) mengemukakan bahwa upaya mengatasi permasalahan pembelajaran daring salah satunya dengan cara mendorong guru untuk kreatif dan inovatif dalam menciptakan pembelajaran daring yang menarik bagi siswa. Utami \& Cahyono (2020), mengungkapkan bahwa solusi dari kesulitan pembelajaran matematika elearning (daring) adalah dengan menerapkan pembelajaran e-learning yang menarik, efektif, dan menyenangkan. Untuk selanjutnya adalah guru atausiswa harus memaksimalkan ketersediaan fasilitas teknologi yang sudah ada, sehingga pembelajaran daring dapat dilakukan maksimal.

\section{SIMPULAN}

Berdasarkan pembahasan dari hasil penelitian yang sudah dilakukan, dapat disimpulkan bahwa masih banyak siswa yang media pembelajarannya menggunakan aplikasi whatsApp selama pandemi ini. Kendala yang dihadapi siswa selama pembelajaraan daring kebanyakan sinyal internet yang kurang memadai di sebagian tempat siswa dan kuota internet, dimana siswa mengeluhkan jika mereka sering kehabisan kuota ketika pembelajaran daring meskipun saat ini pemerintah memberikan bantuan kuota gratis. Penyebab kuota internet cepat habis dikarenakan tugas siswa yang banyak sehingga mereka juga membutuhkan kuota untuk browshing menemukan informasi saat mereka kurang paham terhadap penjelasan yang guru sampaikan. Adapun kesulitan yang dihadapi siswa selama pembelajaran daring matematika, yaitu : (1) terlalu banyak soal yang diberikan (2) terbatasnya ruang interaksi dengan guru,

(3) objek yang dipelajari abstrak, (4) terlalu banyak rumus. Dengan memperhatikan penjabaran kesulitan siswa dalam pembelajaran matematika secara daring solusi yang dapat dilakukan adalah guru memberikan video pembelajaran yang menarik, sehingga siswa lebih paham dengan materi yang disampaikan.

\section{DAFTAR PUSTAKA}

De Porter, Bobbi dan Hernacki, Mike. 1992. Quantum Learning. Membiasakan Belajar Nyaman dan Menyenangkan. Terjemahan oleh Alwiyah Abdurrahman. Bandung: Penerbit Kaifa.

Fauziddin. 2014. Pembelajaran PAUD Bermain Cerita Menyanyi Secara Islami. Bandung. PT. Remaja Rosda Karya.

Sujimat, D. Agus. 2000. Penulisan karya ilmiah. Makalah disampaikan pada pelatihan penelitian bagi guru SLTP Negeri di Kabupaten Sidoarjo tanggal 19 Oktober 2000 (Tidak diterbitkan). MKKS SLTP Negeri Kabupaten Sidoarjo

Suparno. 2000. Langkah-langkah Penulisan Artikel Ilmiah dalam Saukah, Ali dan Waseso, M.G. 2000. Menulis Artikel untuk Jurnal Ilmiah. Malang: UM Press.

UNESA. 2000. Pedoman Penulisan Artikel Jurnal, Surabaya: Lembaga Penelitian Universitas Negeri Surabaya.

Annur, M. F., \& Hermansyah. (2020). Analisis Kesulitan Mahasiswa Pendidikan Matematika Dalam Pembelajaran Daring Pada Masa Pandemi COVID-19. Jurnal Kajian, Penelitian Dan Pengembangan Kependidikan, 11, 195-201.

Kusumaningrum, B., \& Wijayanto, Z. (2020). Apakah Pembelajaran Matematika Secara Daring Efektif? (Studi Kasus pada Pembelajaran Selama Masa Pandemi Covid19). Kreano, Jurnal Matematika KreatifInovatif, 11(2), 136-142. Retrieved from https://journal.unnes.ac.id/nju/index.php/kre ano/article/view/25029

Utami, Y. P., \& Cahyono, D. A. D. (2020). Study At Home: Analisis Kesulitan Belajar Matematika Pada Proses Pembelajaran Daring. Jurnal Ilmiah Matematika Realistik(JI-MR), 1(1), 20-26. 